\title{
PENGARUH WARNA WADAH PADA PERTUMBUHAN DAN PERKEMBANGAN LARVA IKAN RAINBOW KURUMOI (Melanotaenia parva)
}

\author{
Riani Rahmawati” dan Tutik Kadarini \\ Balai Riset Budidaya Ikan Hias \\ Jl. Perikanan No. 13, Pancoran Mas, Depok 16364
}

(Naskah diterima: 5 April 2018; Revisi final: 5 Juli 2018; Disetujui publikasi: 5 Juli 2018)

\begin{abstract}
ABSTRAK
Rainbow kurumoi (M elanotaenia parva) merupakan salah satu ikan endemik Indonesia yang berasal dari Danau Kurumoi, Papua. Ikan ini merupakan salah satu komoditas potensial untuk perdagangan ikan hias. Akan tetapi, pemenuhan permintaan ikan rainbow masih mengandalkan hasil tangkapan alam. Rekayasa lingkungan diperlukan untuk meningkatkan produksi ikan rainbow ini. Penelitian ini bertujuan untuk mengetahui warna wadah yang sesuai untuk optimalisasi pemeliharaan larva ikan rainbow kurumoi. Perlakuan dalam penelitian ini adalah: A) warna wadah merah; B) warna wadah biru; dan C) warna wadah hijau. Larva dipelihara dalam wadah volume $4 \mathrm{~L}$ dengan kepadatan 20 ekor/L selama 28 hari. Pakan yang diberikan berupa infusoria, Rotifer, Artemia, dan Moina secara bertahap dengan metode ad libitum. Hasil penelitian menunjukkan bahwa larva yang diberikan perlakuan beda warna wadah tidak berbeda nyata $(\mathrm{P}>0,05)$ terhadap pertumbuhan dan sintasan. Perlakuan A (warna wadah merah) menunjukkan laju pertumbuhan spesifik panjang tertinggi yaitu sebesar $2,2 \pm 0,1 \%$ hari; dilanjutkan perlakuan $B(2,1 \pm 0,7 \%$ hari); dan terakhir perlakun $C(1,8 \pm 0,7 \%$ hari). Untuk laju pertumbuhan spesifik berat pada perlakuan $\mathrm{A}$ sebesar $6,7 \pm 1,2 \%$ hari; diikuti perlakuan C (6,4 \pm 0,3\% /hari) dan perlakuan B $(5,5 \pm 1,6 \%$ hari $)$. Perkembangan sirip sudah lengkap pada umur 27 hari setelah menetas dengan panjang total tubuh (TL) berkisar antara 8,0-8,6 $\mathrm{mm}$.
\end{abstract}

\section{KATA KUNCl: $\quad$ warna wadah; larva; ikan rainbow kurumoi}

ABSTRACT: The effects of tank colors on growth and development of kurumoi rainbow fish (Melanotaenia parva) larvae. By: Riani Rahmawati and Tutik Kadarini

Rainbow kurumoi (Melanotaenia parva) is one of endemic fish from Kurumoi Lake, Papua, Indonesia. The fish is considered one of the potential commodities in the ornamental fish market. However, to supply the demand for rainbow fish still relies on wild capture. Environmental manipulation is needed to improve the production of rainbow fish. The aim of this study was to evaluate the effects of tank color on the growth of kurumoi rainbow larvae. The treatments in this study were: A) red; B) blue; and C) green tanks. The larvae were reared in the $4 \mathrm{~L}$ volume tanks with a density of 20 ind./L for 28 days. The larvaewere fed, in stages, with infusoria, Rotifer, Artemia, and M oina with ad libitum method. The results showed that the red tank $(A)$ had the highest specific growth rate of length $(2.2 \pm 0.1 \%$ day) followed by blue (B) $(2.1 \pm 0.7 \%$ day) and green (C) $(1.8 \pm 0.7 \%$ day) tanks. The red tank $(A)$ had the highest specific weight growth rate $(6.9 \pm 1.2 \%$ day) followed by the green $(C)(6.4 \pm 0.3 \%$ day) and the lowest was blue $(B)(5.5 \pm 1.6 \%$ day $)$ tanks. The larvae maintained in the red tanks showed brighter color than that of the other two tanks. The fins development has completed on 27 days after hatching (8.0-8.6 mm TL) [ FOR WHICH TANK]. This research indicates that the tank colors do not have any influence on the growth and survival $(P>0.05)$ of rainbow kurumoi larvae.

\section{KEYWORDS: tank color; larvae; kurumoi rainbow fish}

\footnotetext{
\# Korespondensi: Balai Riset Budidaya Ikan Hias. Jl. Perikanan

No. 13, Pancoran Mas, Depok 16364, Indonesia.

Tel. + 62217520482

E-mail: riani_38@yahoo.co.id
} 


\section{PENDAHULUAN}

Ikan rainbow kurumoi (Melanotaenia parva) merupakan salah satu komoditas ikan hias air tawar endemik di Papua, Indonesia (Kadarusman et al., 2010). Menurut Tappin (2010), terdapat 95 jenis ikan rainbow berasal dari Sulawesi dan Papua. Ikan rainbow kurumoi merupakan satu di antara 15 jenis ikan hias tawar yang diminati oleh masyarakat. Adapun 15 jenis ikan hias air tawar tersebut yaitu: arwana, barbus, black ghost, botia, cupang, diskus, frontosa, guppy, koi, lou han, maanvis, maskoki, oskar, platy, rainbow (pelangi) (Lesmana \& Daelami, 2009). Kelimpahan di alam yang kian terbatas, sehingga ikan rainbow kurumoi ini pernah dinyatakan punah oleh IUCN Red List of Threatened Species (IUCN, 2009).

Teknologi budidaya ikan rainbow kurumoi mulai dikembangkan dari tahun 2007 di Balai Riset Budidaya Ikan Hias, Depok. Optimalisasi lingkungan pemeliharaan larva sangat diperlukan untuk meningkatkan kualitas dan kuantitas benih hasil budidaya, karena selama ini pemenuhan permintaan ikan rainbow masih mengandalkan hasil tangkapan alam. Menurut Costa et al. (2016) dan Eslamloo et al. (2015), warna lingkungan merupakan faktor penting dalam budidaya ikan, karena dapat memengaruhi pigmentasi kulit pada beberapa spesies ikan, selain itu, warna latar belakang wadah dapat memengaruhi interaksi sosial ikan (Merighe et al., 2004) atau berkontribusi pada tingkat stres ikan (Papoutsoglou et al., 2000; Rotllant et al., 2003; Papoutsoglou et al., 2005). Perbedaan warna bak pemeliharaan memengaruhi respons pakan dan pertumbuhan (Montajami et al., 2012; Duk-Young \& Hyo-Chan, 2013), perilaku (Ishibashi et al., 2013) dan stres (Banan et al., 2011). Pemilihan warna latar belakang yang sesuai dapat meningkatkan pertumbuhan larva ikan rainbow kurumoi. Menurut Blaxter (1980), akurasi pemangsaan dapat ditingkatkan dengan pemberian warna utama (hue) lingkungan yang dapat menciptakan kekontrasan warna pakan sehingga mudah terdeteksi oleh mata Iarva. Lebih Ianjut menurut Aras et al. (2016), pertumbuhan yuwana ikan botia yang terbaik diperoleh pada perlakuan LED hijau dengan kualitas warna yang terbaik diperoleh perlakuan LED merah dengan peringkat warna Toca color finder (TFC).

Oleh karena itu, perlu dilakukan penelitian rekayasa warna wadah pada pemeliharaan larva ikan rainbow kurumoi. Tujuan penelitian yaitu untuk mengetahui warna wadah yang terbaik dalam pemeliharaan ikan rainbow kurumoi, baik dari segi kualitas maupun kuantitas dalam upaya meningkatkan produksi ikan hias.

\section{BAHAN DAN METODE}

Penelitian ini dilakukan di hatcheri ikan rainbow Balai Riset Budidaya Ikan Hias, Depok. Hewan uji yang digunakan adalah larva yang baru menetas (D-0) dan dipelihara dalam wadah baskom berukuran empat liter, dengan perlakuan beda warna wadah: A) warna wadah merah; B) warna wadah biru, dan C) warna wadah hijau. Perlakuan diulang sebanyak tiga kali dengan rancangan acak lengkap. Kepadatan larva pada masing-masing sebanyak 20 ekor/L. Pakan yang diberikan berupa infusoria, Rotifer, Artemia, dan M oina yang diberikan ad libitum secara bertahap (Tabel 1). Sebagai suplai oksigen, selama pemeliharaan setiap wadah diberikan aerasi dengan gelembung kecil agar tidak mengganggu pergerakan larva. Pengamatan pertumbuhan panjang dilakukan dengan menggunakan mikroskop binokuler Olympus SZX9 dengan perbesaran 8-25x yang telah dilengkapi dengan mikrometer sampai umur 27 hari, dengan jumlah ikan sebanyak 10 ekor per wadah (10\%dari jumlah dalam satu wadah). Pengamatan bobot dilakukan pada akhir pemeliharan dengan menimbang bo bot total ikan yang tersisa dalam satu wadah.

Pengamatan perkembangan larva yang meliputi perkembangan sirip punggung, sirip anal, sirip ekor, dan juga pigmentasinya dilakukan selama 27 hari dengan menggunakan mikroskop binokuler Olympus BX41 dengan perbesaran 4x dan 10x yang dilengkapi dengan kamera digital Panasonic WF-CP240EX. Sampel larva diambil dengan menggunakan pipet plastik $3 \mathrm{~mL}$ dan kemudian ditempatkan pada object glass untuk diamati di bawah mikroskop. Jumlah sampel pada setiap waktu pengamatan adalah tiga ekor larva setiap ulangan. Hasil pemotretan dari mikroskop dianalisis dengan software "Image] ${ }^{\circledR}$ " untuk mendapatkan data pengukuran berdasarkan perbesaran.

\section{HASIL DAN BAHASAN}

Hasil penelitian menunjukkan bahwa perlakuan perbedaan warna wadah tidak berpengaruh nyata $(P>0,05)$ terhadap laju pertumbuhan harian spesifik panjang dan panjang mutlaknya (Gambar 1). Perlakuan dengan pemeliharaan warna wadah merah (perlakuan A) menunjukkan laju pertumbuhan harian spesifik panjang tertinggi, yaitu sebesar 2,2\% /hari $\pm 0,1$; diikuti oleh perlakuan B (warna biru) dan perlakuan C (warna hijau) berturut-turut sebesar 2,1\%/hari $\pm 0,7$ dan $1,8 \%$ hari $\pm 0,7$. Begitu pula dengan panjang mutlak yang didapatkan, pada Gambar 1, menunjukkan perlakuan A (warna wadah merah), lebih tinggi $(3,7$ $\mathrm{mm} \pm 0,3)$ dibandingkan dengan perlakuan $B(3,7 \mathrm{~mm}$ $\pm 1,4)$ dan perlakuan $C(2,9 \mathrm{~mm} \pm 1,6)$. Laju 

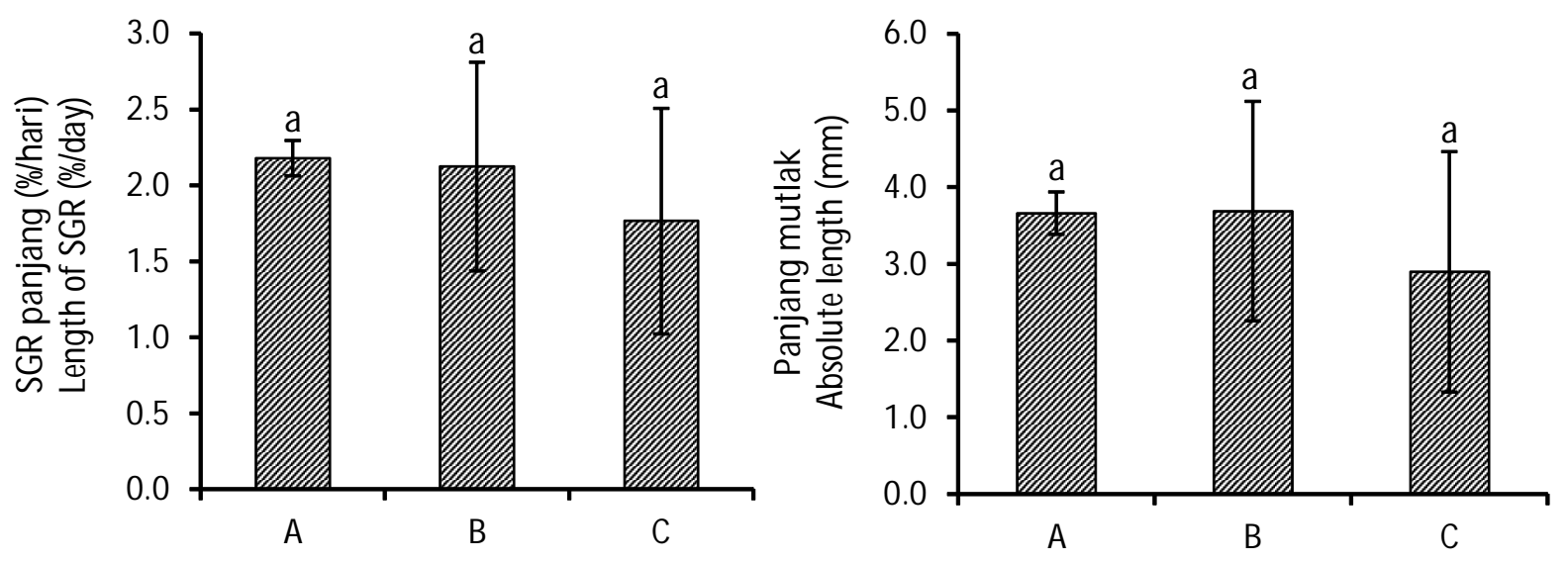

Gambar 1. Pertumbuhan harian panjang spesifik dan mutlak larva ikan rainbow kurumoi (M elanotaenia parva).

Figure 1. Specific growth rate and absolute length of kurumoi rainbow fish (Melanotaenia parva) larvae.

pertumbuhan harian spesifik panjang pada warna merah cenderung sedikit lebih tinggi jika dibandingkan dengan warna lainnya. Hal ini menunjukkan visualisasi pakan lebih kontras dibandingkan wana latar lainnya, sehingga laju pemangsaan terhadap pakan lebih tinggi dan pertumbuhannya lebih tinggi. Sama halnya dengan pertumbuhan dan sintasan spesies lain seperti haddock (M elanogrammus aeglefinus) (Downing\& Litvak, 1999) dan ikan mas (Cyprinus carpio) (Papoutsoglou et al., 2005) yang tidak terpengaruh dengan warna latar belakang hitam, hijau, dan putih. Lebih lanjut menurut (Papoutsoglou et al., 2000; Karakatsouli et al., 2007), setiap spesies memberikan respons terhadap latar belakang yang berbeda, ada beberapa spesies ikan yang menyukai warna latar gelap dan ada beberapa spesies yang dipelihara lebih optimal pada latar terang. Secara umum, tingkat pertumbuhan optimal larva ikan akan tercapai apabila warna latar belakangnya kontras dengan pakan sehingga visualisasi pakan lebih terlihat (Jentoft et al., 2006; Opiyo et al., 2014). Menurut Rotllant et al. (2003), latar belakang warna yang berbeda menyebabkan berbagai respons sehubungan dengan asupan makanan, stres, pertumbuhan, dan sintasan ikan. Hal ini berbeda dengan hasil penelitian pada larva ikan Eurasian perch (P. fluviatilis $L$ ), di mana warna wadah dan intensitas cahaya berpengaruh terhadap pertumbuhan dan sintasan (Tamazouzt et al., 2000).

Perlakuan perbedaan warna wadah tidak berpengaruh nyata $(P>0,05)$ terhadap laju pertumbuhan harian spesifik bobot dan juga bobot mutlak larva ikan rainbow kurumoi (Gambar 2). Perlakuan A (warna wadah merah) menunjukkan laju pertumbuhan bobot spesifik dan bobot mutlak yang lebih tinggi $(6,9 \%$ hari $\pm 1,2$ dan $0,03 \mathrm{~g} \pm 0,010)$ dibandingkan dengan perlakuan $\mathrm{C}(6,4 \%$ hari $\pm 0,3$ dan $0,02 \mathrm{~g} \pm 0,001)$ dan $\mathrm{B}(5,5 \%$ hhari $\pm 1,6$ dan $0,02 \mathrm{~g} \pm$
0,015). Hal ini sesuai dengan hasil penelitian Yosmaniar et al. (2007) yang menyatakan bahwa warna wadah tidak berpengaruh terhadap pertumbuhan larva ikan baung. Lebih lanjut menurut Papoutsoglou et al. (2000), pada pemeliharaan latar belakang hitam, hijau, dan putih menunjukkan bahwa tidak ada perbedaan yang signifikan antar perlakuan terhadap pertumbuhan pada ikan mas selama pemeliharaan.

Pertumbuhan panjang total larva ikan rainbow kurumoi (M. parva) dengan perlakuan perbedaan warna wadah menunjukkan pertumbuhan yang positif mengikuti persamaan linier dengan selang tingkat kepercayaan sebesar koefisien determinasi 98,02\% $98,75 \%$ (Gambar 3). Koefisien variasi pada akhir penelitian selama 27 hari pada perlakuan A sebesar 9,8\% perlakuan B 6,4\% dan perlakuan C sebesar $11,1 \%$ Koefisien variasi yang diperoleh lebih kecil jika dibandingkan dengan penelitian Kadarini et al. (2013) yaitu koefisien variasi pada larva ikan rainbow kurumoi (M. parva) meningkat menjadi $18 \%$ pada hari ke-20. Lebih Ianjut menurut Humprey et al. (2003), pertumbuhan larva ikan Melanotaenia splendida splendida (Peters) meningkat pula dari 3\%menjadi 6\% pada umur 12 hari dan meningkat menjadi 15\%pada umur 87 hari.

Adapun dengan nilai sintasan yang dihasilkan pada Gambar 3. Hal ini menunjukkan bahwa perlakuan perbedaan warna wadah tidak berpengaruh nyata $(P>0,05)$ terhadap sintasan. Besaran nilai untuk perlakuan $\mathrm{A}, \mathrm{B}$, dan $\mathrm{C}$ beturut-turut sebesar $31,3 \% \pm$ 8,$8 ; 26,9 \% \pm 18,6$; dan $23,8 \% \pm 8,8$. Nilai sintasan yang didapatkan cenderung lebih rendah, karena persaingan pakan larva pada awal-awal pemeliharaan (30 hari pertama) sangat tinggi, sehingga larva yang tidak kurang agresif mencari pakan lama kelamaan akan 

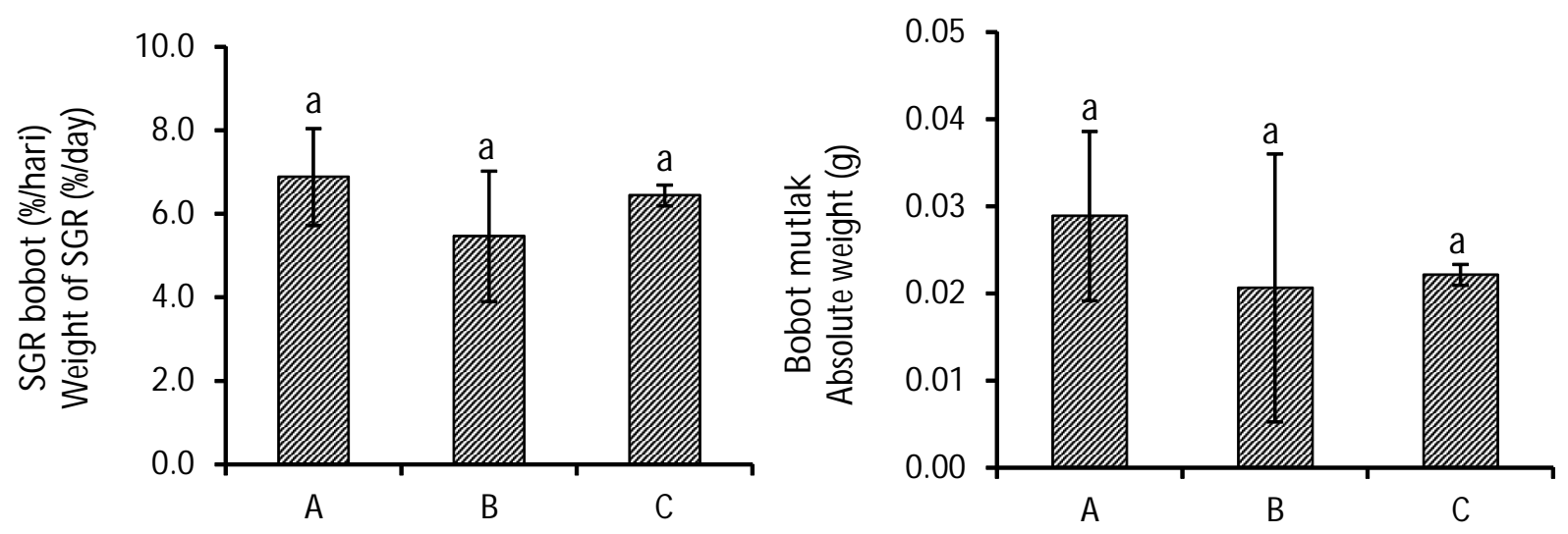

Gambar 2. Pertumbuhan harian berat spesifik dan bobot mutlak larva ikan rainbow kurumoi pada akhir penelitian.

Figure 2. Specific growth rate and absolute weight of kurumoi rainbow fish larvae at the end of experiment.
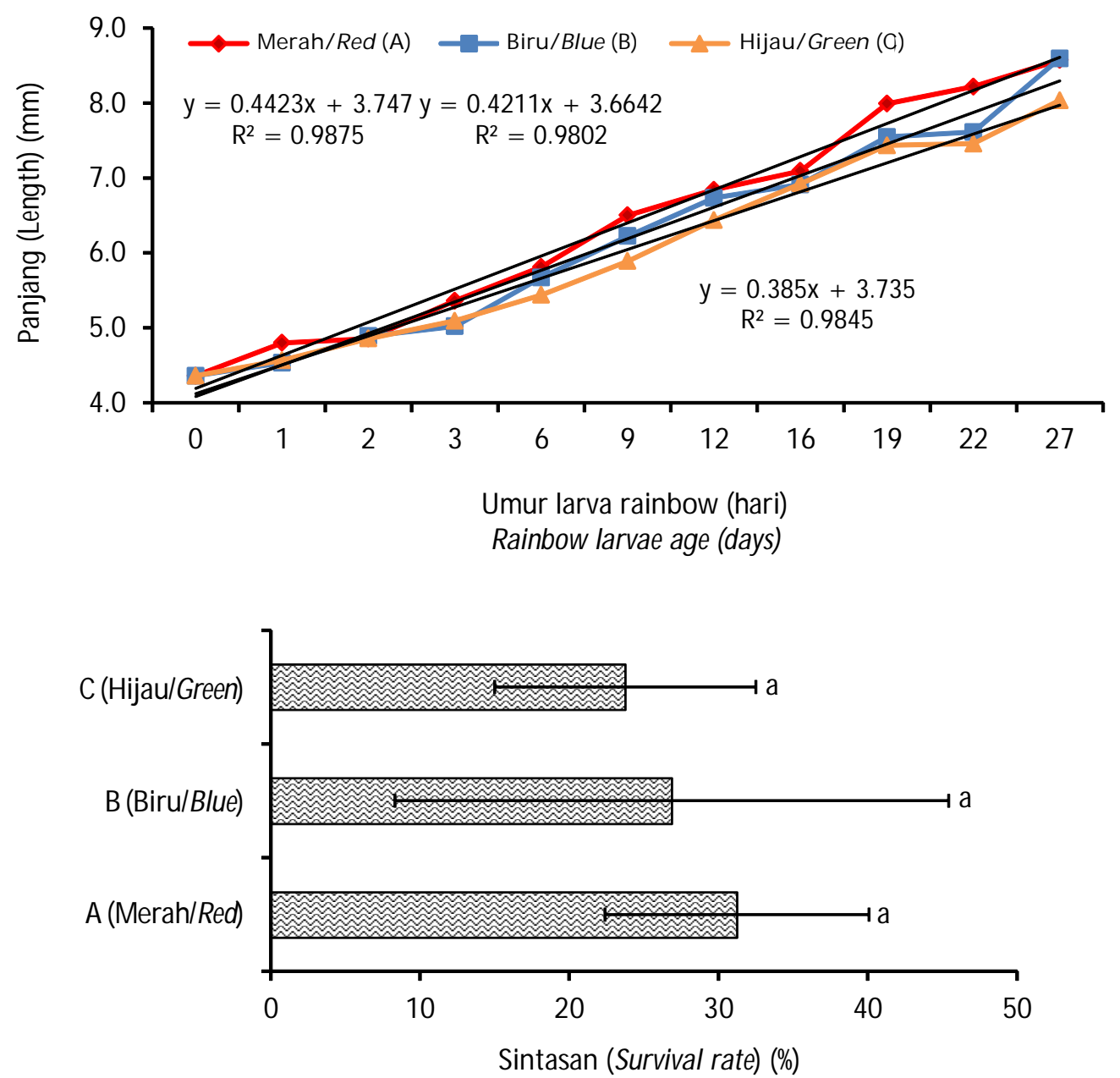

Gambar 3. Pertumbuhan panjang dan sintasan larva ikan rainbow kurumoi (Melanotaenia parva) selama penelitian.

Figure 3. Growth in length and survival rate of kurumoi rainbow fish (Melanotaenia parva) larvae after 28 days of rearing. 
mati. Tingkah laku larva ikan rainbow ini selama 30 hari pemeliharaan cenderung berada pada dasar wadah pemeliharaan. Selain itu, perubahan suhu antara $26,4^{\circ} \mathrm{C}-29,6^{\circ} \mathrm{C}$ (Tabel 2) membuat usaha adaptasi larva dalam wadah pemeliharaan lebih tinggi, sehingga risiko kematian lebih tinggi. Perbedaan wadah ini tidak berpengaruh nyata terhadap sintasan yang diperoleh, hal ini sesuai dengan Yosmaniar et al. (2007) yang menyatakan bahwa warna wadah tidak berpengaruh terhadap sintasan larva ikan baung (18,96\% 19,12\% $18,18 \% 10,50 \%$.

\section{Perkembangan Larva Ikan Rainbow Kurumoi (Melanotaenia parva)}

\section{Perkembangan Sirip}

Pada awal menetas, larva ikan rainbow kurumoi sudah mempunyai sirip ekor, sirip punggung, sirip anal, dan sirip dada yang belum berkembang dengan sempurna. Perkembangan sirip secara sempurna terjadi selama 27 hari, dengan panjang rata-rata berkisar antara 8,0-8,6 mm (Tabel 1). Larva ini sudah mampu berenang di atas permukaan air. Menurut Kadarini et al. (2013), setelah menetas, larva sudah mulai aktif berenang pada permukaan air dengan menggunakan sirip dada dan sirip ekor. Perkembangan larva setelah menetas sudah dimulai dengan pigmentasi di sekitar mata, kepala dan sebagian tubuhnya. Secara umum, sirip punggung, sirip dada, sirip anal, dan sirip ekor sudah berkembang dengan bentuk yang belum definitif. Pada umur 0-5 hari sirip punggung, sirip anal, dan ekor masih menyatu dan masih transparan (Gambar 5; Gambar 6A). Sirip ekor masih berbentuk bulat (rounded).

Pada saat larva berumur 6-8 hari pembelokan tulang ekor mencapai $20^{\circ}$ dan sudah terlihat perkembangan jari-jari di tengah sirip ekor. Sirip punggung, sirip ekor, dan sirip anal masih menyatu (Gambar 4D). Pada saat umur larva 9-15 hari sirip punggung bagian depan mulai menipis dan sudah terdapat jari-jari tulang keras (Gambar 4B dan 4C). sirip anal sudah terlihat jari-jari halus tersusun memanjang (Gambar 5B).

Perkembangan selanjutnya pada umur 16-27 hari, ujung belakang sirip punggung terlihat lekukan yang tegas dan jari-jari tulang keras semakin jelas. Lekuk jari-jari pada ujung bawah sirip anal terlihat jelas dan tulang keras bagian depan menebal (Gambar 4E).

Pada Gambar 5 jari-jari sirip anal mulai mengeras (C), sirip anal sudah memisah dengan sirip ekor dan jari-jari keras mulai menyebar dan tampak jelas (D). Pada umur 27 hari jari-jari keras sirip anal bagian depan makin menebal dan sudah berfungsi sempurna untuk pergerakan berenang. Kadarini et al. (2013) menyatakan bahwa perkembangan sirip pada larva sudah lengkap dan sudah terpisah jelas saat larva berumur 21 hari dengan ukuran panjang total larva rata-rata adalah 11,93 $\mathrm{mm}$ dengan ukuran bukaan mulut mencapai $0,411 \mathrm{~mm}$.

Perkembangan jari-jari sirip ekor pada larva ikan rainbow kurumoi terjadi mulai umur 6-8 hari setelah menetas dengan panjang total 5,4-6,2 $\mathrm{mm}$ yang mengeras pada umur 16-18 setelah menetas dengan panjang total 6,9-7,5 mm. Perkembangan jari-jari selanjutnya diikuti oleh perkembangan sirip punggung dan sirip anal yang mulai mengeras pada umur 16-18 hari dengan panjang total 6,9-8,0 $\mathrm{mm}$. Penggunaan sirip ekor yang merupakan organ penting untuk berenang membuat perkembangan jari-jari terlihat lebih cepat dari perkembangan sirip punggung dan anal. M enurut Kadarini et al. (2013), jari-jari sirip ekor lebih dahulu terbentuk akibat rangsangan pergerakan dari larva saat berenang. Pembelokan tulang ekor
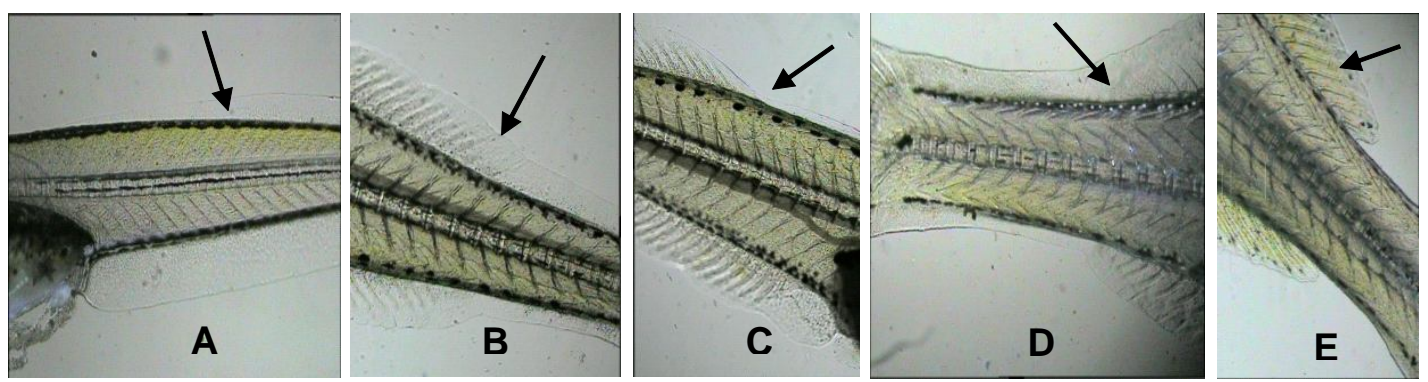

Gambar 4. Sirip punggung masih transparan (A), sirip punggung terdapat jari-jari tulang keras (B), sirip punggung bagian depan mulai menipis (C), sirip punggung bagian belakang masih menyatu dengan sirip ekor (D), dan sirip punggung bagian belakang sudah memisah dan ruas tulang keras semakin jelas (E).

Figure 4. The dorsal fin is still transparant (A), dorsal fin have been formed by the hard fin spines $(B)$, the dorsal fin of the front begins to thin $(C)$, back of dorsal fin and caudal fin are integrated (D), and back of dorsal fin is separated and hard spines are more visible (E). 

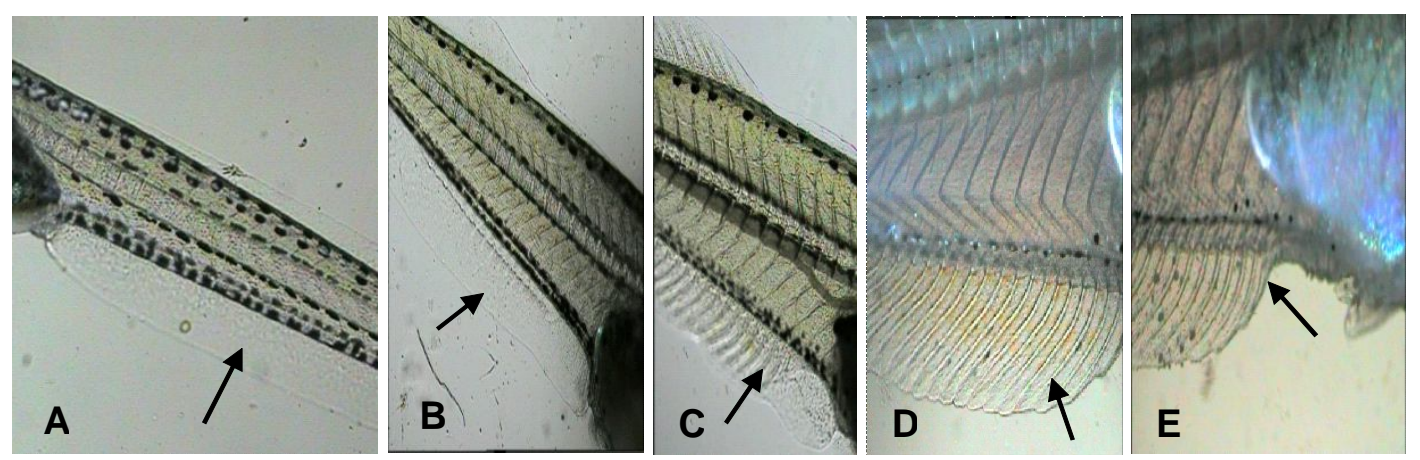

Gambar 5. Sirip anal masih transparan (A), mulai terlihat jari-jari halus pada sirip anal (B), jarijari sirip anal mulai mengeras (C), jari-jari keras sirip anal mulai menyebar (D) dan jari-jari tulang keras bagian depan menebal $(E)$.

Figure 5. Anal fin is still transparent $(A)$, spines of soft rays begin to appear on anal fin(B), the spines of anal fin begin to harden (C), hard spines of anal fin begin to spread (D) and the front spines of anal fin begin to thickened $(\mathrm{E})$.

(notochord) terjadi mulai dari umur larva 5-18 hari (5,4-8,0 $\mathrm{mm} \mathrm{TL})$ secara bertahap mulai dari $5^{\circ}-45^{\circ}$ (Gambar 6). Larva ikan rainbow boesemani usia 11 hari memiliki pembelokan tulang ekor sebesar $30^{\circ}$. Pada usia 13 hari larva ikan rainbow boesemani mengalami pembelokan tulang ekor sebesar $40^{\circ}$ (Yuliani et al., 2013). Lebih lanjut menurut Humprey et al. (2003), terjadinya pembelokan sempurna notochord saat berukuran 7,2 mm (SL).

Pigmentasi pada larva ikan rainbow kurumoi sudah terjadi sejak awal menetas (D-0). Sedikit pigmentasi pada kepala bagian atas dan pada perut bagian dorsal dan ventral. Pigmentasi warna kuning kemerahan pada visualisasi menggunakan mikroskop mulai terjadi pada hari ke-8 pemeliharaan (D-8) untuk perlakuan warna wadah merah, warna biru pada umur ke-11 dan warna hijau pada hari pemeliharaan ke-18 (D-18). Pemunculan warna kuning kemerahan pada perlakuan wadah berwana merah (perlakuan A) diduga dipengaruhi oleh kesesuaian warna lingkungan terhadap warna alami tubuhnya, sehingga perubahan formasi pigmentasi kulit untuk menyesuaikan diri terhadap lingkungannya. Menurut Djamhuriyah et al. (2005), kondisi lingkungan dapat memengaruhi fisiologi sel pigmen sehingga memunculkan perubahan formasi pola pigmen pada tubuh ikan, Kondisi cahaya yang terang akan memberikan penampilan warna yang terbaik dan lebih menarik pada ikan pelangi merah. Begitu pula perubahan formasi warna di udang, menurut Robison $\&$ Charlton (1973), udang mampu merubah warna tubuh mereka untuk berbaur dengan warna latar belakang, melalui pergerakan pigmen pada kromatofor di lapisan epidermal di bawah exoskeleton.

Gambar 7 menunjukkan bahwa pada akhir penelitian, penyebaran warna kuning kemerahan di bawah mikroskop terlihat lebih jelas pada perlakuan
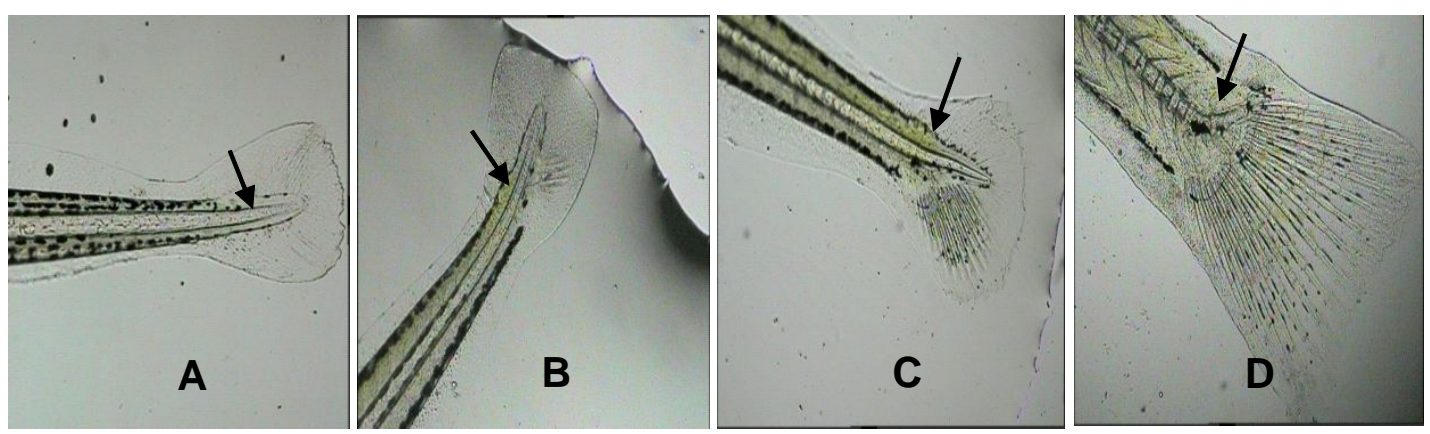

Gambar 6. Perkembangan pembelokan tulang ekor larva ikan rainbow kurumoi (Melanotaenia parva) : A $\left(0^{\circ}\right)$; B $\left(10^{\circ}\right) ; \mathrm{C}\left(20^{\circ}\right)$; D $\left(45^{\circ}\right)$.

Figure 6. Development of notochord deflection of kurumoi rainbow fish (Melanotaenia parva) larvae : A $\left(0^{\circ}\right)$; B $\left(10^{\circ}\right)$; C $\left(20^{\circ}\right)$; D $\left(45^{\circ}\right)$. 
Tabel 1. Perkembangan sirip larva ikan rainbow kurumoi (M elanotaenia parva) selama penelitian Table 1. Fins development of kurumoi rainbow fish (Melanotaenia parva) larvae during observation

\begin{tabular}{|c|c|c|c|}
\hline \multirow{3}{*}{$\begin{array}{l}\text { Umur larva } \\
\text { Age of larvae }\end{array}$} & \multicolumn{3}{|c|}{ Perlakuan wadah (Treatment of tank ) } \\
\hline & Warna merah (Red color) & Warna biru (Blue color) & Warna hijau (Green color ) \\
\hline & A & B & C \\
\hline D-0- D-5 & $\begin{array}{l}\text { Sirip ekor masih berbentuk bulat } \\
\text { (Caudal fin is formed round-shape fin } \\
\text { (rounded) ) } \\
\text { - Pembelokan tulang ekor } 0^{\circ}-5^{\circ} \text { (The } \\
\text { deflection of notochord is at } 0^{\circ}-5^{\circ} \text { ) }\end{array}$ & $\begin{array}{l}\text { - Sirip ekor masih berbentuk bulat } \\
\text { (Caudal fin is formed round-shape fin } \\
\text { (rounded) ) } \\
\text { - Pembel okan tulang ekor } 0^{\circ}-5^{\circ} \text { (The } \\
\left.\text { defl ection of notochord is at } 0^{\circ}-5^{\circ}\right)\end{array}$ & $\begin{array}{l}\text { - Sirip punggung, sirip anal, dan } \\
\text { ekor masih menyatu (Dorsal fin, } \\
\text { caudal fin, and anal fin are } \\
\text { integrated) } \\
\text { - Sirip ekor masih berbentuk bulat } \\
\text { (Caudal fin is formed round-shape fin } \\
\text { (rounded)) } \\
\text { - Pembelokan tulang ekor } 0^{\circ}-5^{\circ} \text { (The } \\
\text { deflection of notochord is at } 0^{\circ}-5^{\circ} \text { ) }\end{array}$ \\
\hline D-6- D-8 & $\begin{array}{l}\text { - Sirip punggung, sirip anal, dan } \\
\text { ekor masih menyatu tapi sudah } \\
\text { mulai menipis (Dorsal fin, caudal } \\
\text { fin, and anal fin are integrated and } \\
\text { morethin) } \\
\text { - } \quad \text { Pembelokan tulang ekor } 20^{\circ} \text { (The } \\
\text { deflection of notochord is at } 20^{\circ} \text { ) } \\
\text { - Terdapat jari-jari pada sirip ekor } \\
\text { bagian tengah (The fin spines is } \\
\text { formed on the center of caudal fin) }\end{array}$ & $\begin{array}{l}\text { - Sirip punggung, sirip anal, dan } \\
\text { ekor masih menyatu tapi sudah } \\
\text { mulai menipis (Dorsal fin, caudal } \\
\text { fin, and anal fin are integrated and } \\
\text { more thin ) } \\
\text { - } \quad \text { Pembelokan tulang ekor } 20^{\circ} \text { (The } \\
\text { deflection of notochord is at } 20^{\circ} \text { ) } \\
\text { - Terdapat jari-jari pada sirip ekor } \\
\text { bagian tengah (The fin spines is } \\
\text { formed on the center of caudal fin) }\end{array}$ & $\begin{array}{l}\text { - Sirip punggung, sirip anal, dan } \\
\text { ekor masih menyatu tapi sudah } \\
\text { mulai menipis (Dorsal fin, caudal } \\
\text { fin, and anal fin are integrated and } \\
\text { more thin ) } \\
\text { - } \quad \text { Pembelokan tulang ekor } 20^{\circ} \text { (The } \\
\text { deflection of notochord is at } 20^{\circ} \text { ) } \\
\text { - Terdapat jari-jari pada sirip ekor } \\
\text { bagian tengah (The fin spines is } \\
\text { formed on the center of caudal fin) }\end{array}$ \\
\hline \multirow[t]{2}{*}{ D-9-D-15 } & $\begin{array}{l}\text { - Sirip punggung sudah mulai } \\
\text { memisah pada bagian depan dan } \\
\text { terdapat jari-jari tulang (Dorsal fin } \\
\text { was separate and fin spines was } \\
\text { formed) } \\
\text { - } \quad \text { Sirip anal sudah terlihat jari-jari } \\
\text { halus tersusun memanjang (Anal } \\
\text { fin have been formed by the fin spines } \\
\text { of soft rays) }\end{array}$ & $\begin{array}{l}\text { - Sirip punggung, sirip anal, dan } \\
\text { ekor masih menyatu tapi sudah } \\
\text { mulai menipis (Dorsal fin, caudal } \\
\text { fin, and anal fin are integrated and } \\
\text { more thin ) } \\
\text { - } \quad \text { Sirip punggung dan sirip anal } \\
\text { sudah terlihat jari-jari halus } \\
\text { tersusun memanjang (Dorsal fin } \\
\text { and anal fin are have been formed by } \\
\text { the fin spines of soft rays) }\end{array}$ & $\begin{array}{l}\text { - Sirip punggung, sirip anal, dan } \\
\text { ekor masih menyatu tapi sudah } \\
\text { mulai menipis (Dorsal fin, caudal } \\
\text { fin, and anal fin are integrated and } \\
\text { more thin) } \\
\text { - Sirip punggung dan sirip anal } \\
\text { sudah terlihat jari-jari halus } \\
\text { tersusun memanjang (Dorsal fin } \\
\text { and anal fin are have been formed by } \\
\text { the fin spines of soft rays ) }\end{array}$ \\
\hline & $\begin{array}{l}\text { - Pembelokan tulang ekor } 30^{\circ} \text { (The } \\
\text { deflection of notochord was } 30^{\circ} \text { ) } \\
\text { - Jari-jari sirip ekor mulai menyebar } \\
\text { (The fin spines of caudal fin was begin } \\
\text { to spread) }\end{array}$ & $\begin{array}{l}\text { - Pembelokan tulang ekor } 30^{\circ} \text { (The } \\
\text { - Jefl ection of notochord was } 30^{\circ} \text { ) } \\
\text { (The fin spines of caudal fin was begin } \\
\text { to spread) }\end{array}$ & $\begin{array}{l}\text { - Pembelokan tulang ekor } 30^{\circ} \text { (The } \\
\text { - Jeflection of notochord was } 30^{\circ} \text { ) } \\
\text { (The fin spines of caudal fin was begin } \\
\text { to spread) }\end{array}$ \\
\hline D-16- D-18 & $\begin{array}{l}\text { - } \quad \text { Sirip punggung sudah memisah } \\
\text { dan jari-jari tulang semakin } \\
\text { mengeras (Dorsal fin was separate } \\
\text { and fin spines more hardened) } \\
\text { - } \quad \text { Jari-jari sirip anal mulai mengeras } \\
\text { dan terlihat lebih jelas (The fin } \\
\text { spines of anal fin more hardened and } \\
\text { cleared) } \\
\text { - } \quad \text { Pembelokan tulang ekor } 45^{\circ} \text { (The } \\
\text { deflection of notochord was) } \\
\text { - Jari-jari sirip ekor mengeras (The fin } \\
\text { spines of caudal fin more hardened) }\end{array}$ & $\begin{array}{l}\text { - } \quad \text { Sirip punggung sudah mulai } \\
\text { memisah dan terdapat jari-jari } \\
\text { tulang keras (Dorsal fin was separate } \\
\text { and fin spines was formed) } \\
\text { - } \quad \text { Jari-jari sirip anal mulai mengeras } \\
\text { dan terlihat lebih jelas (The fin } \\
\text { spines of anal fin more hardened and } \\
\text { cleared) } \\
\text { - } \quad \text { Pembelokan tulang ekor } 45^{\circ} \text { (The } \\
\text { deflection of notochord was) } \\
\text { - Jari-jari sirip ekor mengeras (The fin } \\
\text { spines of caudal fin more hardened) }\end{array}$ & $\begin{array}{l}\text { - } \quad \text { Sirip punggung sudah mulai } \\
\text { memisah dan terdapat jari-jari } \\
\text { tulang keras (Dorsal fin was } \\
\text { separate and fin spines was formed) } \\
\text { - } \quad \text { Jari-jari sirip anal mulai mengeras } \\
\text { dan terlihat lebih jelas (The fin } \\
\text { spines of anal fin more hardened and } \\
\text { cleared) } \\
\text { - Pembelokan tulang ekor } 45^{\circ} \text { (The } \\
\text { deflection of notochord was) } \\
\text { - Jari-jari sirip ekor mengeras (The } \\
\text { fin spines of caudal fin more }\end{array}$ \\
\hline
\end{tabular}


Tabel 1. Lanjutan

Table 1. Continued

\begin{tabular}{|c|c|c|c|}
\hline \multirow{3}{*}{ D-19- D-27 } & $\begin{array}{l}\text { Sirip punggung sudah memisah } \\
\text { dan jari-jari tulang keras semakin } \\
\text { jel as (Dorsal fin was separated and } \\
\text { the hard fin spines more clearly) }\end{array}$ & $\begin{array}{l}\text { - Sirip punggung sudah memisah } \\
\text { dan jari-jari tulang keras semakin } \\
\text { jelas (Dorsal fin was separated and } \\
\text { the hard fin spines more clearly) }\end{array}$ & $\begin{array}{l}\text { - Sirip punggung sudah memisah } \\
\text { dan jari-jari tulang keras semakin } \\
\text { jelas (Dorsal fin was separated and } \\
\text { the hard fin spines more clearly) }\end{array}$ \\
\hline & $\begin{array}{l}\text { Lekuk jari-jari pada ujung bawah } \\
\text { sirip anal terlihat jelas dan tulang } \\
\text { keras bagian depan menebal (The } \\
\text { fin spines on the lower end of anal fin } \\
\text { are clearly and the hard fin spines of } \\
\text { the front thickens) }\end{array}$ & $\begin{array}{l}\text { - Lekuk jari-jari pada ujung bawah } \\
\text { sirip anal terlihat jelas dan tulang } \\
\text { keras bagian depan menebal (The } \\
\text { fin spines on the lower end of anal fin } \\
\text { are clearly and the hard fin spines of } \\
\text { the front thickens ) }\end{array}$ & $\begin{array}{l}\text { - Lekuk jari-jari pada ujung bawah } \\
\text { sirip anal terlihat jelas dan tulang } \\
\text { keras bagian depan menebal (The } \\
\text { fin spines on the lower end of anal fin } \\
\text { are clearly and the hard fin spines of } \\
\text { the front thickens ) }\end{array}$ \\
\hline & $\begin{array}{l}\text { - Ujung sirip ekor sudah berbentuk } \\
\text { cagak (The shape of caudal fin turn } \\
\text { into forked) }\end{array}$ & $\begin{array}{l}\text { - Ujung sirip ekor sudah berbentuk } \\
\text { cagak (The shape of caudal fin turn } \\
\text { into forked) }\end{array}$ & $\begin{array}{l}\text { - Ujung sirip ekor sudah berbentuk } \\
\text { cagak (The shape of caudal fin turn } \\
\text { into forked) }\end{array}$ \\
\hline
\end{tabular}
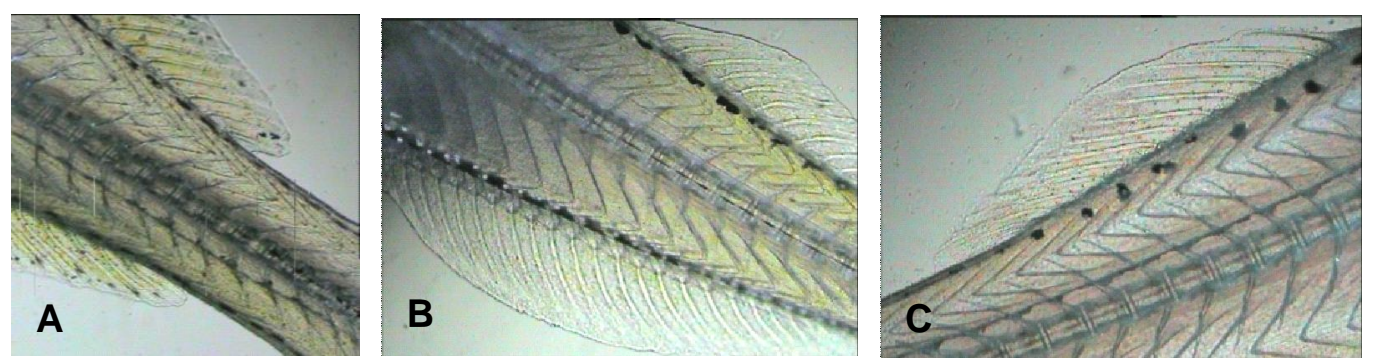

Gambar 7. Pigmentasi larva ikan rainbow kurumoi (M elanotaenia parva) dengan perlakuan perbedaan warna wadah: A (merah); B (biru); C (hijau).

Figure 7. Pigmentation of kurumoi rainbow fish (Melanotaenia parva) larvae treated with different tank colors: A (red); B (blue; C (green).

Tabel 2. Kisaran kualitas air pemeliharaan larva ikan rainbow kurumoi (M elanotaenia parva)

Table 2. Water quality range in kurumoi rainbow fish (Melanotaenia parva) larvae rearing

\begin{tabular}{lcccc}
\hline \multicolumn{1}{c}{$\begin{array}{c}\text { Parameter } \\
\text { Parameters }\end{array}$} & A & B & C & $\begin{array}{c}\text { Referensi } \\
\text { Reference (Tappin, 2010) }\end{array}$ \\
\hline Suhu/Temperature $\left({ }^{\circ} \mathrm{C}\right)$ & $26.4-29.1$ & $26.8-29.4$ & $26.8-29.6$ & $20-30$ \\
$\mathrm{pH}$ & $5.2-6.8$ & $5.0-6.3$ & $5.6-6.5$ & $6.5-7.8$ \\
Oksigen terlarut/Dissolved oxygen $(\mathrm{mg} / \mathrm{L})$ & $8.15-8.69$ & $8.48-8.6$ & $7.26-8.24$ & $>5$ \\
\hline
\end{tabular}

warna wadah merah (perlakuan A). Visualisasi warna wadah yang sesuai akan memunculkan warna ikan yang lebih cerah. Warna latar belakang yang berbeda pada pemeliharaan ikan bisa menyebabkan perubahan warna kulit menjadi gelap, hal ini disebabkan terjadinya perubahan pigmentasi kulit yaitu dengan dispersi konsentrasi pigmen dalam kulit melanophores kulit (Rotllant et al., 2003; Eslamloo et al., 2013). Warna latar belakang berbeda ditangkap oleh mata dan kelenjar pineal ikan, sehingga bisa memodulasi sekresi hormon melatonin, a-melanocyte-stimulating hormone (aMSH) (Rotllant et al., 2003) dan hormon konsentrat melanin (KIA) (Amiya et al., 2005).
Monitoring kualitas yang meliputi suhu, $\mathrm{pH}$, dan DO (dissolved oxygen), pada Tabel 2 menunjukkan bahwa masih dalam kisaran yang baik untuk menunjang pertumbuhan larva ikan rainbow kurumoi (M. parva).

\section{KESIMPULAN}

Perlakuan perbedaan warna wadah pada pemeliharaan larva ikan rainbow kurumoi (M elanotaenia parva) tidak berpengaruh nyata $(P>0,05)$ terhadap sintasan dan pertumbuhan. Perkembangan sirip sudah lengkap pada umur 27 hari stelah menetas $(8,0-8,6 \mathrm{~mm} \mathrm{TL})$. 


\section{UCAPAN TERIMA KASIH}

Ucapan terima kasih kami sampaikan kepada tim rainbow Balai Riset Budidaya Ikan Hias (BRBIH) Depok yang telah membantu selama penelitian ini berlangsung.

\section{DAFTAR ACUAN}

Amiya, N., Amano, M., Takahashi, A., Yamanome, T., Kawauchi, H., \& Yamamori, K. (2005). Effects of tank color on melanin-concentrating hormone levels in the brain, pituitary gland, and plasma of the barfin flounder as revealed by a newly developed time-resolved fluoroimmunoassay. General and Comparative Endocrinology, 143, 251-256.

Aras, A.K., Nirmala, K., Soelistyowati, D.T., \& Sudarto. (2016). Manipulasi spektrum cahaya terhadap pertumbuhan dan kualitas warna yuwana ikan botia Chromobotia macracanthus (Bleeker, 1852). Jurnal Iktiologi Indonesia, 16(1), 45-55.

Banan, A., Kalbassi, M .R., Bahmani, M., \& Sadati, M.A.Y. (2011). Effects of colored light and tank color on growth indices and some physiological parameters of juvenile beluga (Huso huso). Journal of Applied Ichthyology, 27, 565-570.

Blaxter, J.H.S. (1980). Vision and the feeding of Fish. In Bardach, J.E.J.J. p. 32-56.

Costa, D.C., Mattioli, C.C., Silva, W.S., Takata, R., Leme, F.O.P., Oliveira, A.L., \& Luz, R.K. (2016). The effect of environmental colour on the growth, metabolism, physiology and skin pigmentation of the carnivorous freshwater catfish Lophiosilurus alexandri.Journal of Fish Biology, 14 pp.

Djamhuriyah, S.S., Supyawati, W.D., \& Noortiningsih. (2005). Pengaruh jenis pakan dan kondisi cahaya terhadap penampilan warna ikan pelangi merah, Glossolepis incices Jantan, Jurnal Iktiologi Indonesia 5(2), 61-67.

Downing, G. \& Litvak, M.K. (1999). The effect of photoperiod, tank colour and light intensity on growth of larval haddock, Aquaculture International, 7,369-382.

Duk-Young, K. \& Hyo-Chan, K. (2013). Influence of density and background color to stress response, appetite, growth and blind-side hypermelanosis of flounder, Paralichthys olivaceus. Fish Physiology and Biochemistry, 39, 221-232.

Eslamloo, K., Akhavan, S.R., Eslamifar, A., \& Henry, M.A. (2013). Effects of background colour on growth performance, skin pigmentation, physiological condition and innate immune responses of goldfish, Carassius auratus. Aquaculture Research, p. 1-14.
Eslamloo, K., Akhavan, S.R., Eslamifar, A., \& Henry, M.A. (2015). Effects of background colour on growth performance, skin pigmentation, physiological condition and innate immune responses of goldfish, Carassius auratus. Aquaculture Research, 46, 202-215.

Humphrey, C., Klumpp, D.W., \& Pearson, R. (2003). Early development and growth of the eastern rainbowfish, Melanotaenia splendida (Peters) I. In Marine and Freshwater Research, CSIRO Publishing, Morphogenesis and Ontogeny, p. 17-25.

Ishibashi, Y., Izumi, T., Kurata, M., \& Okada, T. (2013). Effects of tank wall pattern on survival, bone injury rate and stress response of juvenile Pacific bluefin tuna, Thunnus orientalis. Aquacultural Engineering, 56, 13-17.

IUCN. (2009). The IUCN red list of threatened species (M. parva). http://www.iucnredlist.org/details/ 13072/0.

Jentoft, S., Øxnevad, S., Aastveit, A.H., \& Andersen, $\emptyset$. (2006). Effects of tank wall colour and up-welling water flow on growth and survival of Eurasian perch larvae (Perca fluviatilis). Journal of the World Aquaculture Society, 37, 313-317.

Kadarini, T., Zamroni, M., \& Pambayuningrum, E.K. (2013). Perkembangan larva ikan rainbow kurumoi (Melanotaenia parva) dari hasil pemijahan. J. Ris. Akuakultur, 8(1), 77-86.

Kadarusman, Sudarto, Paradis, E., \& Pouyaud, L. (2010). Description of Melanotaenia fasinensis, A new species of rainbow fishes (Melanotaeniidae) from West Papua, Indonesia with comment on the rediscovery of $M$. ajamaruensis and the endangered status of M. Parva. Cybium, 34(2), 207-215.

Karakatsouli, N., Papoutsoglou, S.E., \& Mano-lessos, G. (2007). Combined effects of rearing density and tank colour on the growth and welfare of juvenile white sea bream Diplodus sargus $L$. in a recirculating water system. Aquaculture Research, 38, 1152-1160.

Lesmana, D.S. \& Daelami D. (2009). Panduan lengkap ikan hias air tawar populer. Jakarta: PenebarSwadaya, $267 \mathrm{hlm}$.

Merighe, G.K.F., Pereira-da-Silva, E.M., Negrão, J.A., \& Ribeiro, S. (2004). Effect of background colour on the social stress of nile tilapia (Oreochromis niloticus). Revista Brasileira de Zootecnia, 33, 828837.

Montajami, S., Nekoubin, H., Mirzaie, F.S., \& Sudagar, M. (2012). Influence of different artificial colors of light on growth performance and survival rate 
of Texas cichlid larvae (Herichthys cyanoguttatus). World Journal of Zoology, 7, 232-235.

Opiyo, M.A., Ngugi, C.C., \& Rasowo, J. (2014). Combined effects of stocking density and background colour on growth performance and survival of nile tilapia (Oreochromis niloticus, I.) fry reared in aquaria. Journal of Fisheries Sciences, 8(3), 228-237.

Papoutsoglou, S.E., Mylonakis, G., Karakatsouli, N.P., $\&$ Chadio, S. (2000). Effects of background color on growth performances and physiological responses of scaled carp (Cyprinus carpio, I.) reared in a closed circulated system. Aquacultural Engineering, 22, 309-318.

Papoutsoglou, S.E., Karakatsouli, N., \& Chiras, G. (2005). Dietary L-tryptophan and tank colour effects on growth performance of rainbow trout (Oncorhynchus mykiss) juveniles reared in a recirculating water system. Aquaculture Engineering, 32, 277-284.

Rotllant, J., Tort, L., Montero, D., Pavlidis, M., Martinez, M., Wendelaar Bonga S.E., \& Balme, P.H.M. (2003). Background colour influence on the stress response in cultured red porgy Pagrus pagrus. Aquaculture, 223, 129-139.
Robison, Jr.W.G. \& Charlton, J.S. (1973). Microtubules, microûlaments, and pigment movement in the chromatophores of Palaemonetes vulgaris (Crustacea). J. Experimental Zoology, 186, 279-304.

Tamazouzt, L., Chatain, B., \& Fontaine, P. (2000). Tank wall colour and light level affect growth and survival of Eurasian perch larvae (Perca fluviatilis L.). J. Aquaculture, 182, 85-90.

Tappin, A.R. (2010). Rainbow fishes: Their care \& keeping in captivity. Australia: Art Publication, 493 $\mathrm{pp}$.

Yosmaniar, Taufik, I., \& Sutrisno. (2007). Komunikasi ringkas pengaruh perbedaan warna wadah terhadap sintasan dan pertumbuhan larva ikan baung (Hemibagrus nemurus Blkr.). J. Ris. Akuakultur, 2(3), 425-429.

Yuliani, F., Musthofa, S.Z., Kadarini, T., \& Elfidasari, D. (2013). Perkembangan larva ikan rainbow boesemani (Melanotaenia boesemani): tahap pembentukan sirip dan pembelokan tulang ekor. Unnes. J. Life Sci., 2(2), 100-104. 